\title{
Indikátorové sady sociálního prostředí v podmínkách slovenských obcí
}

\section{Indicator sets of social environment in terms of Slovak municipalities}

\author{
Milan Douša, Lenka Pčolinská \\ https://doi.org /10.33542/VSS2019-2-04
}

\begin{abstract}
The issue of measuring and evaluating sustainable development at local level is becoming increasingly widespread as development monitoring is the basis for understanding the current situation and predicting future developments. This gradually led to the need to create indicators of sustainable development, respectively indicators evaluating the development of its three pillars (economic, social and environmental) approved by the UN in 2015 called Agenda 2030. The aim of the paper is to compile indicator sets for evaluation of social sustainable in small municipalities in the Slovak Republic. To fulfill the aim of the paper we did an analysis and comparison of the current indicator sets that served us for our preliminary design of an indicator set of social environment, which can be used to explore or measure social sustainability in smaller municipalities of up to 2000 inhabitants.
\end{abstract}

Keywords: social environment, sustainable development, Slovak villages, social indicators, sustainable development goals

\section{Úvod}

Koncept trvale udržitelného rozvoje je $v$ popředí zájmu odborné a laické veřejnosti již od roku 1992, kdy byla na Summitu Země v Rio de Janeiro vyhlášena Agenda 21. Udržitelný rozvoj je chápán především jako rovnováha mezi třemi základními piliři: ekonomickým, sociálním a environmentálním (Šilhánková a kol. 2012). V řadě oblastí došlo k propracování teoretických přistupů k rozvoji, resp. plánování rozvoje. Př́kladem může být propracování metodiky tzv. Místní Agendy 21 a implementace jejich principů ve strategických plánech municipalit (zatím spíše výjimečně) i zavedení těchto principů do plánování udržitelného rozvoje na krajské úrovni. Celý tento proces je potom završen národní strategií udržitelného rozvoje. Všechny tyto teoretické prístupy a $z$ nich vzešlé praktické dokumenty směřují $k$ vytvoření takové situace $v$ rozvoji společnosti, která přinese nejen trvale vyvážený př́stup $\mathrm{k}$ jednotlivým složkám společnosti - ekonomické, environmentální a sociální oblasti, ale i 
vyvážený rozvoj jednotlivých regionů, tj. snižování existujících regionálních disparit (Šilhánková a kol. 2012).

V současné společnosti roste zájem o indikátory pro sociální prostředí. Tento zájem nově posílily tzv. Cíle udržitelného rozvoje (Sustainable Development Goals). Existují různé indikátory měření sociálního piliřre, například: indikátor kvality sociálního prostředí, indikátor sociodemografické struktury obyvatel obce, indikátor míry spokojenosti a participace na věcech veřejných a mnohé dalši (Kučerová 2009). Měření sociální koheze je řešeno na lokální (úroveň měst nad 10000 obyvatelů), republikové úrovni a $v$ mezinárodním měřítku, nesetkáváme se však s řešením tohoto tématu na úrovni malých obcí (do 2000 obyvatel).

Doposud jsou indikátorové sady tvořeny zejména na mezinárodní a národní úrovni. Avšak i z národní úrovně můžeme vysledovat iniciativy, které se zabývají udržitelným rozvojem a jeho měřením na úrovni měst. Patří sem například sady OECD, Sustainability Cities International, UN-Habitat, Společné evropské indikátory - ECI, Urban Sustainability Indicators a mnohé další. V České republice, Slovenské republice i zahraničí se však do popředí zájmu postupně dostávají také sady, které definují indikátory sociální udržitelnosti také na místně specifické úrovni, tj. zabývají se kontextem měst a komunit $v$ užším regionu konkrétně země. Tyto indikátory se však zaměřuji zejména na velká a střední města nad 10000 obyvatel, kupříkladu Sustainable Seatle, STAR Communities (USA) nebo Metodika hodnocení udržitelných měst (Česká republika). V České republice je jednou z nejznámějších publikací Metodika hodnocení udržitelných měst, jež přináší podrobný popis evaluace za pomoci tzv. Auditu udržitelného rozvoje (Dobeš kol. 2017). V Slovenské republice bohužel žádná taková metodika neexistuje. Audit v ČR je zaměřen na 10 základních témat rozvoje města v souladu s mezinárodními Aalborskými závazky. Audit hodnotí stav a trendy ve sledovaných tématech sohledem na dlouhodobý udržitelný rozvoj města. Metodika byla vytvořena jako nástroj zejména pro realizátory metody místní Agenda 21 (MA21) v České republice. Zpracovaný Audit je základem pro strategické řízení komplexního rozvoje na místní úrovni. $\vee$ tomto ohledu jsou zpracování Auditů a postup dle Metodiky doporučeny k využití ve Zdravých městech, obcích a regionech. Audit by měl být jedním z významných analytických podkladů pro strategické a koncepční dokumenty každé udržitelné municipality. První verze Metodiky byla schválena Pracovní skupinou MA21 při Radě vlády pro udržitelný rozvoj (RVUR) v březnu 2012. Metodika byla dále aktualizována v letech 2013 a 2015. Metodika hodnocení MA21 se již měřením na lokální úrovni zabývá, ale prozatím se zaměřuje na velké města, nikoliv na malé obce, které např. v Slovenské republice převažují díky fragmentované sídelné struktuře. Co však ve světě chybí, jsou indikátory pro malé obce, tj. obce do 2000 obyvatel. Tyto obce jistě také chtějí řešit problematiku udržitelnosti v rovině ekonomické, sociální i environmentální. Podmínky takových obcí se však významně liší od podmínek velkých a středních měst, a to jak $v$ oblastech, které stojí v centru zájmu z hlediska udržitelného rozvoje, tak v systému 
měření a implementace opatření. V rámci našeho příspěvku jsme se rozhodli analyzovat právě sociální piliřr konceptu udržitelného rozvoje.

\section{Sociální piliǐr konceptu udržitelného rozvoje}

Sociální dimenze udržitelného rozvoje se ukázala jako nejobtížněji zachytitelná. Mezi zeměmi OECD existují značné rozdily v tom, jak interpretují sociální udržitelnost: od chudoby v rozvojovém světě ke zdravotním následkům environmentální změny, záležitostem vztahujícím se k etnickým minoritám až k širším záležitostem kvality života a sociálních vztahů (chudoba, trestná činnost, vzdělávání atd.) (Czesený 2006).

V posledních letech se sociální udržitelnost stala důležitou součástí hlavního politického diskursu západních vlád, které se pokoušely identifikovat problémy spojené s tímto konceptem (Colantonio 2007). Jak uvádí Colantonio (2007) s odkazem na zprávu Evropského panelu pro udržitelný rozvoj (2004), Evropská rada na zasedání v Lisabonu v roce 2000 poprvé představila myšlenku sociální dimenze jako nedílnou součást modelu udržitelného rozvoje. Velká část lisabonských závěrů se týkala čtyř hlavních aspektů sociální udržitelnosti. Jednalo se o závazek zlepšit vzdělávání, zejména ve vztahu k novým dovednostem potřebným pro ekonomiku založenou na znalostech, přeformulovat politiku zaměstnanost, tak aby se vytvářela "lepší pracovní místa", modernizaci sociální ochrany, aby se přizpůsobily mnoha výzvám, kterým čelí sociální státy, aby se "zaplatila práce" a podpořila rovnost, a rozvoj strategie proti chudobě a sociálnímu vyloučení prostřednictvím "podpory sociálního začleňování".

Colantonio (2007) chápe sociální udržitelnost jako aspekt udržitelnosti, který se týká osobních a společenských aktiv, pravidel a procesů, které umožňují jednotlivcům a komunitám účastnit se dlouhodobého a spravedlivého dosažení přiměřených a ekonomicky dosažitelných životních standardů, založených na sebevyjádření potřeb a aspirací v rámci fyzických hranic míst a planety jako celku. Specificky se problematice určování konkrétních prvků sociálního piliře věnují rovněž experti na místní úrovni. V červnu 2004 v Aalborgu se konala Evropská konference udržitelných měst, známá jako Aalbor+10. Mezi důležité oblasti k projednání patřily sociální rovnost a spravedlivost, zejména se usilovalo o vytvoření a implementaci programů prevence a zmírnění chudoby, zajištění rovného přistupu k veřejným službám, vzdělání, zaměstnání, přiležitostem, zvyšování kvalifikace, informacím, kultuře. Pozornost byla rovněž věnována pomoci při zařazení do společnosti a rovnosti pohlaví, zlepšení jistoty a bezpečnosti v obci, zajištění kvalitního a sociálně-integrovaného bydlení a životních podmínek (Národní sít' Zdravých měst České republiky). Podrobnější definici sociální udržitelnosti se zvláštním zaměřením na městské prostředí poskytují Polese a Stren (2000) "je to rozvoj (a/nebo růst), který je slučitelný s harmonickým vývojem občanské společnosti, podporující prostředí vedoucí ke slučitelnému soužití kulturně a sociálně rozmanitých skupin a zároveň podporující sociální 
integraci se zlepšenim kvality života všech segmentů populace” Jejich definice zdůrazňuje ekonomické (rozvojové) a sociální (občanské společnosti, kulturní rozmanitost a sociální integraci) rozměry udržitelnosti. Uznávají však také význam fyzického prostředí (např́klad bydlení, urbanizmus a veřejné prostory) v rámci diskuze o udržitelnosti měst. $V$ posledních letech je účast na interaktivní správě věcí veřejných a zapojení veřejnosti do plánování rozvojových projektů považováno za základní prvek sociální udržitelnosti a provádění politik udržitelného rozvoje. Jak uvádí, Lupala s odkazem na UN-Habitat (2001) inkluzívní městská správa snižuje nerovnost a sociální napětí, zahrnuje znalosti, produktivitu, sociální a fyzický kapitál chudých a znevýhodněných v rozvoji města a zvyšuje místní odpovědnost za vývojové procesy a programy. Z hlediska infrastruktury a praktického pohledu Ize rozšírit argument, že rostoucí počet domácností s omezeným přístupem $\mathrm{k}$ pitné vodě, elektřině a slušnému bydlení představuji hlavní rozměry vyloučení. Omezený přístup k základním službám, jako jsou například kvalitní zdravotní a vzdělávací služby, jsou také součástí sociálního vyloučení (Lupala 2014).

\subsection{Sociální prostředí a jeho vztah k sociálnímu pilíri udržitelnosti}

V řade prací, dokumentů a také $v$ prostředí Slovenské republiky se velmi často setkáváme s pojmem sociální prostředí. S tímto pojmem mimo jiné pracuje rovněž strategický dokument "Metodika hodnocení udržitelných měst ČR 2017". Elizabeth Barnett a Michele Casper (2001) přináší definici pojmu sociální prostředí: "Sociální prostředí člověka zahrnuje bezprostřední fyzické prostředí, sociální vztahy a kulturní prostředí, v němž určité skupiny lidí funguji a interaguji”. Dále uvádí, že součástí sociálního prostředí je vybudovaná infrastruktura, pracovní trhy, sociální a ekonomické procesy, sociální, personální a zdravotnické služby, mocenské vztahy, vláda, rasové vztahy, společenská rovnost, resp. nerovnost, kulturní postupy, umění, náboženské instituce a praktiky, přesvědčení o místě a společenství. Sociální prostředí zahrnuje mnoho aspektů fyzického prostředí, protože současná krajina, vodní zdroje a další prírodní zdroje byly alespoň částečně konfigurovány lidskými společenskými procesy. Sociální prostředí Ize prožívat v různých měřítcích, často současně, na úrovni domácností, čtvrtí, měst a regionů. Sociální prostředí je dynamické a mění se v průběhu času (Barnett, Casper 2001). Další definici uvádí U. S. National Library of Medicine (2019): "Sociální prostředí je souhrn sociálních a kulturních institucí, forem, vzorců a procesů, které ovlivňují život jednotlivce nebo komunity“.

Sociální prostředí se skládá ze součtu názorů, zvyků, praktik a vzorců chování společnosti. Je to do značné míry umělý konstrukt, který může být kontrastován s přirozeným prostředím, ve kterém žijeme. Pojem sociální prostředí vychází z termínu sociální piliř udržitelného rozvoje, má však specifickou charakteristiku, vztahující se spíše na uplatnění na 
lokální úrovni. Charakteristickými rysy sociálního prostředí jsou bydlení, doprava a sousedské vztahy (Třebický 2009).

Na tom jaké jsou sociální vztahy ve společnosti a jak je rozvinutá infrastruktura závisí další důležité životní složky, jako jsou např. zdraví, vzdělávání, ekonomický standard města/obce, kultura, atd. Sociální faktory prostředí, kupříkladu bezpečnost, násilí a sociální selhání obecně, také specifické faktory související s typem, kvalitou a stabilitou sociálních vazeb, včetně sociální účasti, sociální soudržnosti, sociálního kapitálu a kolektivní podpory mají vliv na zdravotní stav obyvatelstva. Například, charakteristiky sociálního prostředí, které mohou působit jako stresory (včetně vnímání bezpečnosti a sociálních poruch), souvisí s duševním zdravím, stejně jako faktory, které by mohly napravit nepřiznivé účinky stresu (např. sociální soudržnost a sociální kapitál). Jedním z mechanismů, který to může napravit a zlepšit zdraví obyvatel je sociální podpora. Sít' sociálních vztahů je důležitým zdrojem podpory a zdá se, že má významný vliv na zdraví obyvatel (Třebický 2009).

Zajímavé se také jeví pojímání sociálního prostředí v iniciativě Happy City (Št’astné město). Happy City zachycuje determinanty individuálního blahobytu, ale s ohledem na faktory, které jsou důležité pro komunitu jako celek (Brown 2017). Spokojenost s komunitou může být považovaná za víc než součet dobrých životních podmínek jednotlivců. Podstatné jsou v rámci této iniciativy také faktory, jako posouzení vztahů v rámci komunity (jako je důvěra a sounáležitost, relativní postavení jednotlivců v komunitě atd.) Významné jsou též faktory, které ovlivňují subjektivní blahobyt komunity. $\vee$ rámci toho iniciativa zahrnuje nezávislost, pocit štěstí, spokojenost se životem a hodnoty. Faktory $v$ Hospodářské oblasti jsou: nezaměstnanost, kvalita zaměstnání, materiální deprivace. Do oblasti Vzdělávání a děti je zařazeno učení dětí a dospělých a také blahobyt dětí. Do oblasti Rovnost patři nerovnost blahobytu, do Zdraví patři zdravotní chování, mentální a celkové zdraví. Do oblasti Místo patři zelený prostor, podmínky bydlení, demokracie, lokální prostředí, kriminalita a bezpečnost, kultura. Poslední oblastí jsou Sociální vztahy, kam patří podpora blízkých, obecná důvěra, osobní vztahy, komunitní soudržnost a dobrovolnictví. K principům sociální udržitelnosti patři vzájemná interakce, demokracie a dobré vládnutí, spravedlnost, rozmanitost a kvalita života (Brown 2017).

Kvalita sociálního prostředí je nedílnou součástí kvality života jako celku. Sociální prostředí města formuje jeho tvář, naše dojmy a emoce, které na nás ve městě působí. Sociální prostředí vytváŕi sociální struktura jedinců i sociální chování skupiny. Sociální prostředí spoluvytváří též míra komunitního života, sociální soudržnosti, role občanské společnosti a obecně zájem o věci společné (Kučerová 2009). 


\subsection{Objektivní a subjektivní indikátory sociálního prostředí}

Klíčovým nástrojem při posuzování míry sociální udržitelnosti jak na globální, národní, tak i lokální úrovni je určení vhodných indikátorů, které představují jasné a určité informace obvykle v číselné podobě, které mají dobrou vypovídací schopnost, to znamená, že sdělují důležitá a všem srozumitelná fakta. Údaje indikátorů musí být jednoduše pochopitelné, a pritom odborně správné (Moldan 1996). Mohou mít kvantitativní a kvalitativní podobu. Od 90. let se staly indikátory součástí mnoha politických dokumentů na národní a místní úrovni, například Společné Evropské Indikátory $(E C I)$. V současné době je cesta $v$ Evropě i v Slovenské republice a České republice usnadněna nejen dobrými pozitivními příklady, ale také jasnou legislativou, morálně pak "Chartou evropských měst a obcí směřujících $k$ trvale udržitelnému rozvoji” (tzv. Aalborgskou chartou), která byla schválena účastníky Evropské konference měst $v$ dánském Aalborgu $v$ roce 1994 jako rozhodující podpůrný materiál pro současné aktivity UNEP, WHO, EU, OECD a řady mezinárodních odborných společností světa, stejně jako vládních či nevládních organizací národního charakteru (Národní sít' Zdravých měst ČR 2019).

Objektivní indikátory se vztahují k realitě v rámci teritoriální jednotky a jsou indikátory "prostředí", kde lidé žijí. Tím pádem je možné porovnat společnosti s využitím indikátorů nebo indexů, které shrnují různé důležité objektivní sociální indikátory (Petrucci, D’Andrea 2002). Objektivní indikátory odráží socio-ekonomickou situaci, objektivní blahobyt (well-being) země. Kupříkladu, hlavní ekonomické indikátory odráží celkovou národní politickou a ekonomickou situaci (Petrucci, D’Andrea 2002). K objektivním indikátorům patří například demografické údaje (demografické stárnutí, nízká porodnost, migrační saldo), ekonomické údaje (HDP), nezaměstnanost mladých lidí, dospělých a žen, genderová nerovnost (mezi nezaměstnaným a zaměstnaným obyvatelstvem), údaje o zdravotním systému (lůžka na osobu, lékař na osobu), nedostatek silniční infrastruktury, sociální znepokojení (míry sebevražd). Kvalitu městského prostředí můžeme hodnotit pomocí takových objektivních indikátorů, jakými jsou např. Vybavenost lokality, míra kriminality, kvalita bydlení, počet mateřských škol. $V$ tomto případě používáme nejčastěji dostupná sekundární data nebo vycházíme z primárních dat získaných na základě terénních šetření provedených ve zkoumaných lokalitách (Dvořáková 2010).

Subjektivní indikátory naopak vyjadřují emoce, očekávání, naděje a frustraci obyvatelstva, aspekty, spojené s lokální situací. Subjektivní indikátory jsou ovlivněny kulturními a historickými faktory, tradicemi, zvyky a někdy "rezignaci", která vede k různému vnímání zdánlivě ukotvených situací. Realita v evropských státech se liší mezi sebou podle posuzování subjektivního hodnocení, kdy se ptáme, jak lidé (skupiny osob, uživatelů) vnímají a hodnotí podmínky kolem sebe. Zjištuje se prostřednictvím různých metod, např. Dotazníkového 
šetření, řízených rozhovorů, mentálních map a (ne)zúčastněných pozorování (Dvořáková 2010).

Subjektivní a objektivní indikátory přispívají lepšímu pochopení potřeb a přání společnosti, zároveň pomáhají správnému zhodnocení vnějších podmínek a potenciálu územní jednotky v rámci trvale udržitelného rozvoje.

\section{Data a metodika výzkumu}

V príspěvku jsme použili všeobecné výzkumné metody, a to obsahovou analýzu dokumentů, syntézu, selekci a vztahovou komparaci. Nejdřive byla v príspěvku provedena obsáhlá analýza vybraných dokumentů a publikací, konkrétněji řečeno indikátorových sad na lokální úrovni se zaměřením na sociální oblast. Jedná se o indikátorové sady organizací a iniciativ jako například SDGs, Mezinárodní standard ISO 37120 Udržitelný rozvoj komunit Indikátory pro městské služby a kvalitu života ISO 37120 z roku 2014, Urban Sustainability Indicators (Indikátory udržitelnosti měst), Místní rozvoj vedený komunitou (Community-led local development European Structural and Investment Funds), RFSC (The Reference Framework for Sustainable Cities), Urban Indicators for Managing Cities, Sustainable Cities International, Urban Indicators Guidelines - UN Human Settlements Programme, Společné evropské indikátory, Metodika hodnocení udržitelných měst, CIVITAS, Sustainable Seattle, CERCLE Indicateurs, North Durham Integrated Community Sustainability Plan, STAR Communities a další.

Analýza a syntéza již existujících indikátorových sad přináší komplexní pohled na to, jakým způsobem pojímají různé, národní a lokální instituce a rozvojové programy termín sociálního prostředí a co všechno do tohoto pojmu zahrnují. Celkem bylo analyzováno 30 institucí a rozvojových programů, z nichž 9 organizací a iniciativ se zabývá hodnocením sociální udržitelnosti na globální úrovni, 6 - na národní a 15 - na místní úrovni. Celkový počet indikátorů v rámci analýzy byl 419. Na základě vztahové komparace vybraných indikátorových sad vyplývajících z analýzy byly vytipovány indikátory sociálního prostředí, které se v jednotlivých sadách opakují. Tím jsme zjistili, které indikátory se považují za nejdůležitější na všech úrovních (globální, národní, lokální) uplatňování principů trvale udržitelného rozvoje. Výsledky analýzy a syntézy následně obsahovali celkem 36 tematických oblastí a 41 indikátorů.

Dalším důležitým krokem byla selekce z řad průniků, kdy jsme vytipovali indikátory, které odpovídají vymezení pojmu sociálního prostředí na místní úrovni. Na tomto základě byl vytvořený vlastní návrh indikátorové sady, který obsahuje 6 tematických oblastí a 23 indikátorů sociálního prostředí. Tato identifikace indikátorů by měla posloužit jako prvotní krok pro potřeby měření sociálního piliře udržitelnosti v obcích do 2000 obyvatelů. 
Pro účel vedení budoucích polo-strukturovaných rozhovorů a přehlednost návrhu, byl indikátorový set uveden do tabulky. Každý z vybraných indikátorů je zařazen do určitého tematického okruhu, dále jsou uvedeny název indikátoru a jeho definice. Tabulka zahrnuje celkem 6 tematických oblastí a 23 indikátorů v oblasti sociálního prostředí jako objektivní, tak i subjektivní povahy. $V$ př́padě testování navrhnuté sady indikátorů bude tato sada respondentům $\mathrm{k}$ dispozici. $\mathrm{V}$ prípadě samotné realizace rozhovorů v terénu ( $\mathrm{v}$ obcích do 2000 obyvatelů) by byl kladený důraz na zodpovězení dvou klíčových otázek, a to jsou: "zda vytvořená sada indikátorů odpovídá požadavkům a možnostem slovenských obcí do 2000 obyvatel" a "jestli v sadě nechybí tematické oblasti, resp. indikátory, které jsou podle názoru respondentů důležité pro malé obce".

\section{Analýza vybraných indikátorových sad na lokální úrovni}

Indikátorové sady pro hodnocení sociálního prostředí na lokální úrovni předpokládají využití indikátorových sad ve městech, obcích, komunitách. Následující iniciativy a programy rozvoje nabízí indikátorové sady pro uplatnění na úrovni měst pro mezinárodní porovnání. Pro účely naplnění cíle našeho př́spěvku jsme v této kapitole charakterizovali zkoumané indikátory trvale udržitelného rozvoje na různých úrovních jednotlivých organizací, iniciativ a rozvojových programů. Celkem bylo v rámci níže uvedených analyzováno 419 indikátorů. Následuje základní charakteristika (popis) jednotlivých metrik.

Mezinárodní standard ISO 37120 Udržitelný rozvoj komunit - Indikátory pro městské služby a kvalitu života ISO 37120 z roku 2014 se vztahuje na všechna města, obce nebo místní samosprávy, které se zavazují měřit svou výkonnost srovnatelným a ověřitelným způsobem bez ohledu na velikost a polohu. Indikátory a metody $v$ této mezinárodní normě pomáhají městům nejenom měřit řízení výkonnosti městských služeb a kvalitu života $v$ průběhu času, města se také učí od sebe navzájem umožňovat srovnání v širokém spektru výkonnostních opatření a $v$ neposlední řadě sdílí osvědčené postupy. Do sociální oblasti zahrnuje témata, jako jsou nezaměstnanost, počet požárníků a dobrovolníků ve městě/obci, sebevraždy, veřejný prostor, bezpečnost, sociální vyloučení, bezdomovectví (ISO 37120 2014). Urban Sustainability Indicators (Indikátory udržitelnosti měst) jsou důležitými nástroji pro hodnocení výkonu měst. Zahrnují environmentální, ekonomické a sociální indikátory určené k odhalení pokroku při plnění cílů udržitelnosti chápaných v nejširším smyslu. Mnoho evropských měst pracuje se specifickými sadami indikátorů, které jim umožňují měřit jejich úspěch při dosahování svých cílů a sdělovat výsledky iniciativ, které jim byly učiněny. Nadace vytvořila společný rámec ukazatelů městské udržitelnosti pro města na základě Charty evropských udržitelných měst. Tato zpráva popisuje širokou škálu indikátorových opatření s cílem vytvořit index udržitelnosti měst. $V$ rámci sociální oblasti řeší otázky chudoby, nedostatku přistupu ke vzdělání a odborné přípravě. Také se věnuje bezpečnosti ve městě a občanské 
participaci (Mega, Pedersen 1998). Místní rozvoj vedený komunitou (Community-led Local Development) je nástrojem pro zapojení občanů na místní úrovni při vytváření reakcí na sociální, ekologické a ekonomické výzvy, kterým čelíme v současné době. CLLD (Communityled Local Development) je přístup, který vyžaduje čas a úsilí, ale pro relativně malé finanční investice to může mít výrazný dopad na životy lidí a vytváření nových myšlenek a společných závazků $\mathrm{k}$ jejich uvedení do praxe. CLLD může být užitečným nástrojem pro posílení místních komunit, včetně znevýhodněných skupin, ke zlepšení institucionální kapacity místních zúčastněných stran a zejména nevládních organizací a pro spuštění sociálních inovací na místní úrovni (European Commission 2019). RFSC (The Reference Framework for Sustainable Cities) je iniciativa ve formátu internetového nástroje, který byl vytvořen, aby umožnil implementaci Lipské Charty (Leipzig Charter) pro udržitelná evropská města v návaznosti na deklaraci Marseille evropských ministrů zodpovědných za udržitelné města. Mottem RFSC je "snaha o zelená, inkluzivní a atraktivní města". Urban Indicators for Managing Cities poskytuje soubor indikátorů pro města v regionu Asie a Tichomoří. Asijská banka rozvoje chápe důležitost používání indikátorů a benchmarkingu. Pro tento účel vyvinula metodologii a kritéria měření a hodnocení efektivity poskytování městských služeb a sít' pro výměnu informací o kvalitě a efektivnosti poskytování služeb a řízení měst (Westfall, De Villa 2001). Hlavními tématy, týkající se sociální oblasti, jsou: zmírnění městské chudoby, zlepšení kvality a kvantity sociální infrastruktury, zahrnující míru kriminality a gramotnosti, podpora inovativních systémů bydlení a legalizace neformálního bydlení (squatters atd.), kvalita městských služeb jako voda, elektřina, sanitace apod. Sustainable Cities International je nezisková organizace, která se specializuje na oblast městské udržitelnosti. Sídlí ve Vancouveru, spolupracuje s městy po celém světě a zaměřuje se na budování lidských kapacit $\checkmark$ rámci měst takovým způsobem, aby vznikaly inovace a změny. $V$ sociální oblasti tato instituce klade dưraz na zajištění základní infrastruktury, přistupu obyvatelstva k místním službám v krátké vzdálenosti, sledování míry kriminality, sociální bydlení, školy s programy environmentálního vzdělávání, míru gramotnosti dospělých atd. (SCI 2012). Urban Indicators

Guidelines - UN Human Settlements Programme jsou urbanistické indikátory, které jsou pravidelně shromažd’ovány ve vzorcích měst po celém světě, aby bylo možné podávat zprávy o pokroku ve dvaceti klíčových oblastech agendy Habitat na úrovni měst. Sběr dat probíhá prostřednictvím místních a národních městských observatoří i prostřednictvím vybraných regionálních institucí. Globální databáze městských indikátorů obsahují indikátory orientované na politiku ve více než 200 městech po celém světě. Výsledky byly analyzovány ve Zprávě o stavu světových měst za rok 2001. V sociální sféře se věnuje tématưm: připojení ke službám, kriminalita, chudé domácnosti, vzdělání (gramotnost), genderová inkluze, růst městské populace, domy $\vee$ nebezpečných lokalitách, doba jízdy do práce, neformální zaměstnání, nezaměstnanost, občanská angažovanost atd. (UN-Habitat 2004). Společné evropské 
indikátory neboli indikátory $\mathrm{ECI}$ (European Common Indicators), jsou nejznámější a nejvyužívanější sadou udržitelného rozvoje na místní úrovni v krajinách EU. V sociální oblasti se zabývá jak subjektivními (např. Spokojenost občanů $\mathrm{s}$ místním společenstvím), tak $\mathrm{i}$ objektivními indikátory, týkající se témat mobility a místní přepravy cestujících, nezaměstnanosti atd. (Společné evropské indikátory ECI 2019). CIVITAS je indikátorová sada, založená na sadě Společných evropských indikátorů. Je prezentována v Metodice sledování udržitelného rozvoje na místní úrovni, která vznikla na základě výzkumného projektu WD 6907-4 "Indikátory trvale udržitelného rozvoje jako nástroj sledování a snižování disparit v úrovni obyvatelstva jednotlivých regionư". Indikátorová sada CIVITAS je rozdělena do tří částí: Sociálně-demografická struktura, která se mimo jiné zabývá tématem nezaměstnanosti, Sociální prostředí, které se věnuje dostupnosti klíčových služeb, sledování míry kriminality ve městě/obci, genderové rovnosti při obsazení vedoucích pozic a třetí velké téma se nazývá Spokojenost a participace na věcech veřejných, které se zaobírá otázkami spokojenosti občanů s místním společenstvím, volební účastí a výdaji na kulturu (Šilhánková 2012). Sustainable Seattle je jednou z prvních organizací vůbec, která vytvořila indikátory udržitelnosti. Nezisková organizace byla založena v roce 1991 a zaměřuje se na dlouhodobou udržitelnost, spravedlnost a resilienci v regionu Central Puget Sound. Za důležité považuje spolupráci, dobré vládnutí a sociální spravedlnost. CERCLE Indicateurs je národní sít určená k měření trvale udržitelného rozvoje $v$ kantonech a městech Švýcarska. North Durham Integrated Community Sustainability Plan je rozsáhlý a podrobně zpracovaný plán udržitelného rozvoje severního Durhamu, USA. STAR Communities čili Sustainability Tools for Assessing \& Rating Communities je nezisková organizace založená ve Washingtonu D. C., která pracuje na hodnocení, zlepšování, benchmarkingu a certifikaci udržitelných komunit. (STAR Communities 2017).

Na základě těchto organizací, iniciativ a rozvojových programů jsme provedli vztahovou komparaci jednotlivých indikátorových sad a vybrali jsme vhodné sociální indikátory, podle frekvence jejich výskytu, tedy opakování v jednotlivých sadách. Tab. č. 1 shrnuje opakující se 36 tematických oblastí zahrnující 41 indikátorů sociálního piliře. Není překvapením, že se na prvním místě v žebříčku významnosti nachází téma nezaměstnanosti $s$ indikátorem Míra nezaměstnanosti, který dosáhl maximální hodnoty frekvence $v$ porovnání $s$ ostatními indikátory. Nejméně často se opakují indikátory, týkající se oblasti zdraví, a konkrétně spotřeby tabákových výrobků a alkoholu za rok, počet smrtelných dopravních nehod, doby odezvy služby nouzového volání, domácího násilí, vnímání bezpečnosti občany, demografické struktury a rovného přistupu obyvatel k základním službám. 


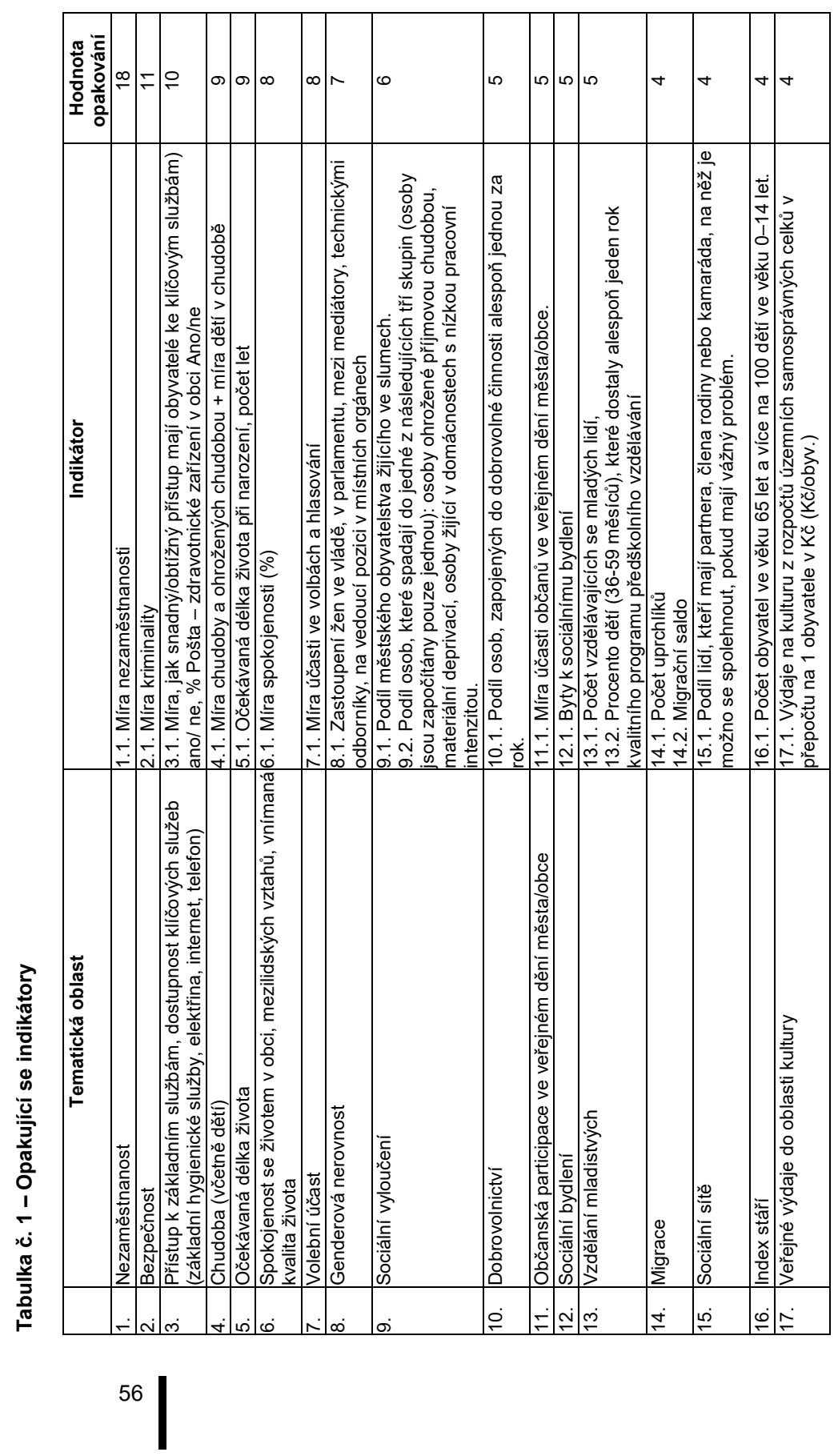




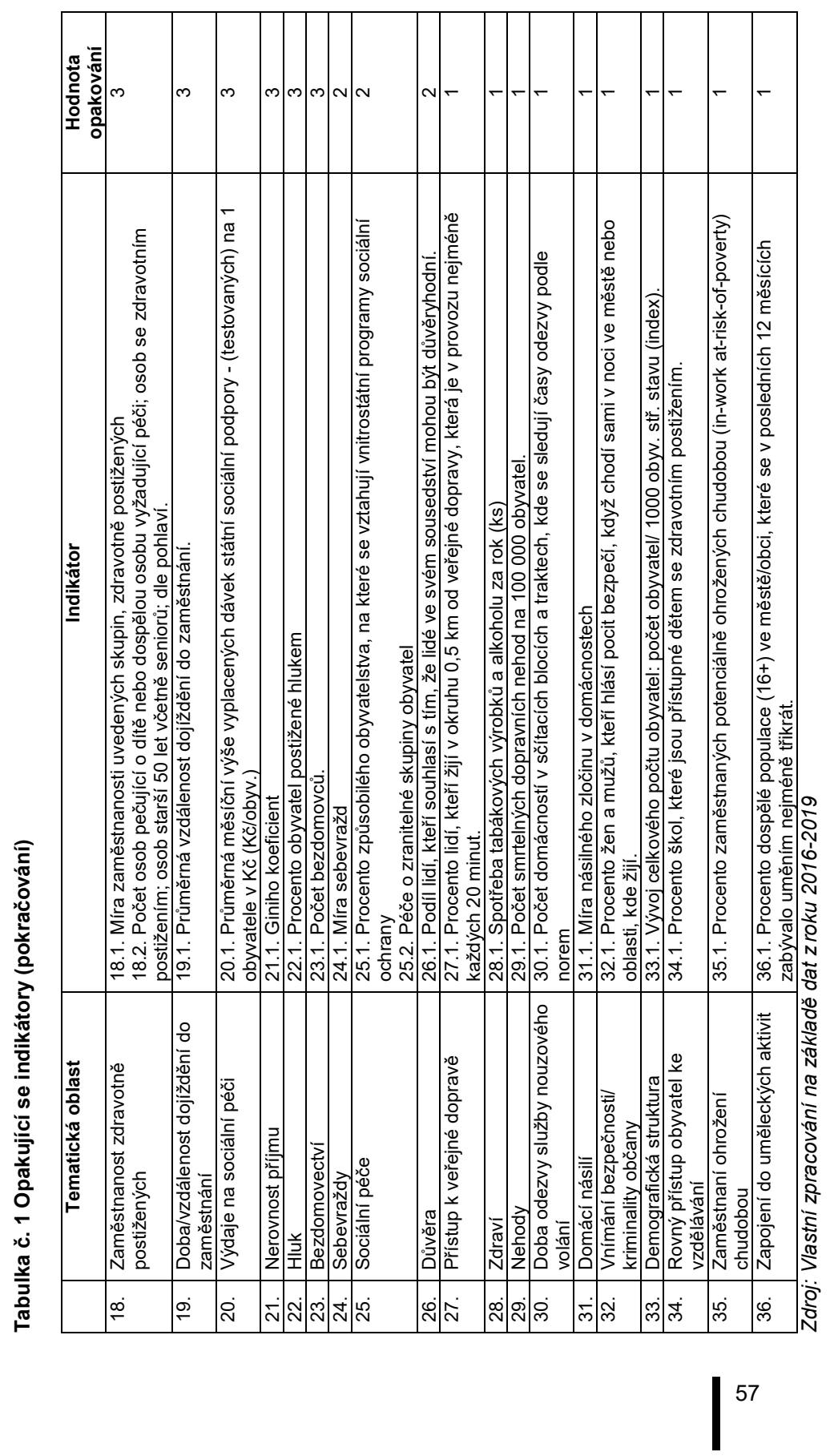




\subsection{Návrh indikátorové sady}

Výstupem analýzy byl návrh na zpracování indikátorové sady pro potřeby hodnocení menších obcí do 2000 obyvatel pro poměry aplikování této sady v Slovenské republice.

Na základě poznatků jak z teoretické části, zejména vymezení pojmu sociální prostředí, vybraných indikátorových sad a na základě specifického charakteru malých obcí v Slovenské republice (fragmentovaná sídelná struktura), byla sada opakujících se indikátorů upravena a revidována, a to následovným způsobem. Indikátory z tematických oblastí jako je Zdraví, Vzdělávání a výchova, Kultura a zapojení občanů do uměleckých aktivit, Doprava (nehody) byly vyřazeny ze sady, stejně tak jako indikátory opakující se pouze jednou. Tyto indikátory byli vyřazené zdůvodu malého výskytu (frekvence opakování). Indikátory jako míra nezaměstnanosti, Giniho koeficient pro měření nerovnosti př́ijmu, demografická struktura a index stáři jsou důležitými ukazateli sociální oblasti. Pro účely malých obcí je však nutné tyto indikátory zjednodušit nebo zařadit do jiných oblastí, například sociálně-ekonomických nebo sociálně-demografických indexů a indikátorů. Navrhovaná sada je tedy upravena tak, aby odpovídala požadavkům a možnostem většiny slovenských obcí do 2000 obyvatel.

Tabulka č. 2 znázorňuje návrh indikátorové sady sociálního prostředí, vypovídající o tematické oblasti $v$ rámci sociálního prostředí, následuje název indikátoru a jeho definice. Návrh obsahuje 6 tematických oblastí a 23 indikátorů sociálního prostředí, jako východiska z rešeršní části práce a analýzy stávajících indikátorových sad na třech úrovních pro tvorbu předběžného návrhu indikátorové sady. Tato sada indikátorů je sestrojená tak, aby byla aplikovatelná $v$ podmínkách trvale udržitelného rozvoje vobcích do 2000 obyvatelů v Slovenské republice.

$S$ ohledem na to, abychom mohli aplikovat a měřit sociální prostředí z hlediska udržitelnosti i v menších obcích na Slovensku, jsme považovali za důležité vybrat ty indikátory, které mohou odrážet reálný stav udržitelnosti sociálních aspektů v obcích na Slovensku. Tato navrhovaná sada indikátorů sociálního prostředí je tedy, podle autorů príspěvku plně kompatibilní se současnými podmínkami, specifikami a problémy slovenských obcí do 2000 obyvatelů. Tento návrh indikátorové sady sociálního prostředí by byl následně v rámci dalšího výzkumu diskutován s experty na indikátory sociálního prostředí a zástupci vybraných malých obcí v SR v rámci polo strukturovaných rozhovorů v našem dalším výzkumu. 


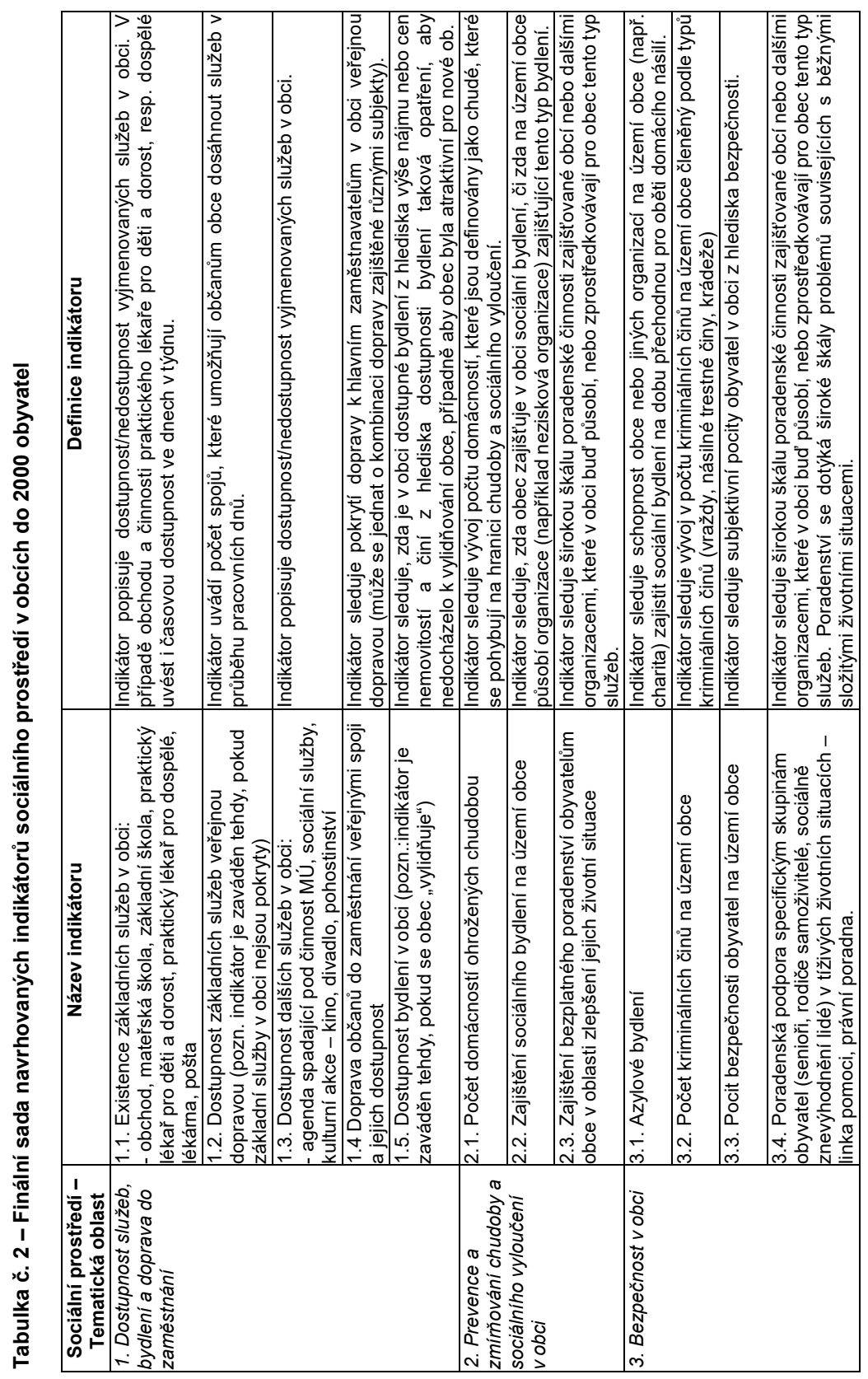




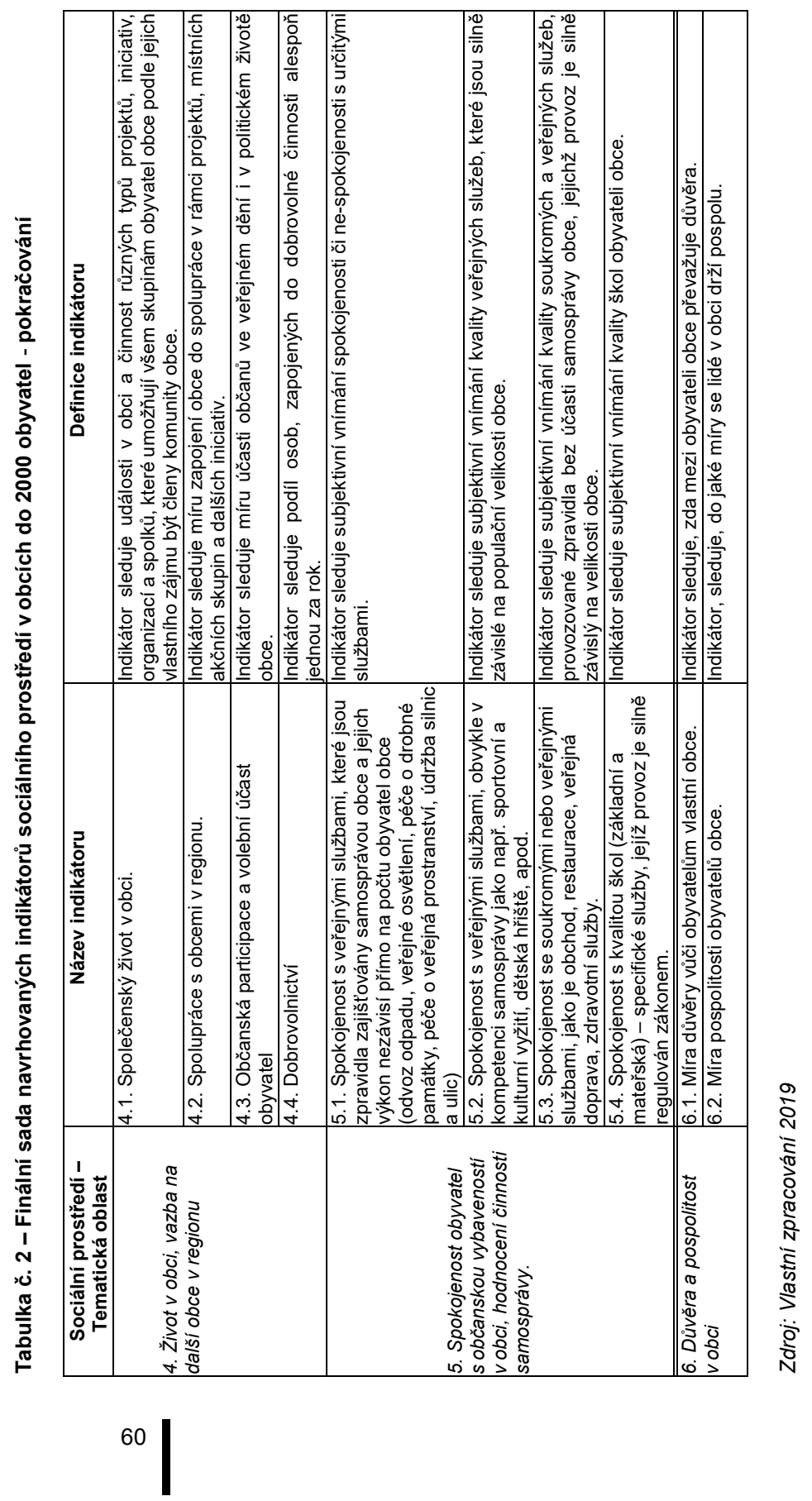




\section{Závěr}

Cílem tohoto príspěvku bylo najít způsob měření sociálního prostředí z pohledu Cílů udržitelného rozvoje (Sustainable Development Goals) v prostředí menších obcí, a to konkrétně obcí s počtem obyvatel do 2000 . Indikátorové sady, které ve světě existují, pokrývají témata, které jsou aplikovatelné převážně na větší sídla. V Slovenské republice taková metrika zatím neupravují, ani při větších městech. S ohledem na to, abychom mohli aplikovat a měřit sociální prostředí z hlediska udržitelnosti i v menších obcích na Slovensku, jsme považovali za důležité vybrat ty indikátory, které mohou odrážet reálný stav udržitelnosti sociálních aspektů v obcích na Slovensku. Článek přináší návrh vybraných indikátorů, na základě hloubkové analýzy a komparace stávajících indikátorových sad a je připraven pro testování v terénu, v prostředí obcí s počtem obyvatel 2000 . Naším záměrem je využít tuto indikátorových sadu nejprve jako testovací metriku, prostřednictvím rozhovorů se starosty vybraných obcí, kteří by posoudili relevanci jednotlivých indikátorů a jejich vhodnost pro prostředí menších obcí. Věříme, že předkládaný návrh může posloužit $\mathrm{k}$ lepšímu posouzení naplňování cílů udržitelnosti v podmínkách České republiky a Slovenské republiky. V Slovenské republice dochází k problému vylidňování malých obcí do 2000 obyvatel a nárůstu migrace do měst. $Z$ toho důvodu považujeme za důležité věnovat pozornost obcím do 2000 obyvatel v Slovenské republice. Zvyšovat jejich atraktivitu právě prostřednictvím inteligentních udržitelných rešení (Smart Village) a způsobu jejich měření (indikátorů udržitelnosti), které povedou kzvýšení kvality života v těchto obcích.

Prezentovaný př́spěvek je součástí řešeni projektu VVGS na roky 2019-2020 s názvem: Dynamika rozvoja sociálnej ekonomiky na Slovensku a jej využitie v samospráve.

\section{Literatúra:}

BARNETT, E. - CASPER, M. 2001. A Definition of „Social Environment“. In: American Journal of Public Health. Research. Vol. 91. No. 3. [online]. [cit. 20.9.2019]. Dostupné z: <http://ajph.aphapublications.org/doi/pdf/10.2105/AJPH.91.3.465a>.

BROWN, H. 2017. Understanding local needs for wellbeing data: measures and indicators. [online]. [cit. 21.9.2019]. Dostupné z: <http://www.happycity.org.uk/wp-content/uploads/2017/08/Understanding-local-needs-for-wellbeing-data-JULY-2017.pdf>.

COLANTONIO, Andrea. 2007. Social Sustainability: An Exploratory Analysis of its Defi- nition, Assessment Methods, Metrics and Tools. In: Measuring Social Sustainability: Best Practice from Urban Renewal in the EU. Oxford Brooks University, Oxford Institute for Sustainable Development (OISD) - International Land Markets Group, Oxford, UK. [on- line]. [cit. 17.9.2019]. Dostupné z: <http://oisd.brookes.ac.uk/sustainable_communities/resources/SocialSustainability_Metrics_and_Tools.pdf>.

CZESANÝ, S. 2006. Indikátory udržitelného rozvoje. In: Statistika. 5/2006. Praha: Český statistický úřad, s. 431-434. [online]. [cit. 15.9.2019]. Dostupné z: 
<file://Users/dina/Downloads/Hák\%201/Indik\%20udrzitelnosti/dalsi\%20cteni/Indikatory\%20UR-\%20Czesany.pdf >.

DOBEŠ, V. a kol. 2017. Metodika hodnoceni udržitelných měst: Audit udržitelného rozvoje pro realizátory MA21 v ČR. Verze 2017. 136 s. ISBN 978-80-906033-2-5 [online]. [cit. 14.9.2019]. Dostupné z: <https://www.data- plan.info/img_upload/f96fc5d7def29509.

DVOŘÁKOVÁ, N. 2010. Kvalita života/ Quality of life. Komunitní studie lokalit: pre- zentace. [online]. [cit. 2017-11-22]. Dostupné z: <http://docplayer.cz/29943814-Kvalita-zi- vota-qualityof-life-mgr-nina-dvorakova-ksgrr-2010-komunitni-studie-lokalit.html>.

EUROPEAN COMMISSION. 2019. CLLD. [on-line]. [cit. 25.9.2019]. Dostupné z: https://enrd.ec.europa.eu/leader-clld/clld-partner-search/active/_en f\%5B0\%5D=im_field _enrd_coop_topic_of_proj\%3A20092\&f\%5B1\%5D=im_field_enrd_coop_topic_of_proj\% $3 \bar{A} 20$ 065 .

ISO 37120:2014. 2014. Sustainable development of communities: Indicators for city servi- ces and quality of life. 85 s. 13.020.20. Environmental economics. Sustainability.

KUČEROVÁ, Z. 2009. Indikátory sociálního piliře udržitelného rozvoje na lokální úrovni. In: XIII. Vědecká konference doktorandů. Vysoké učení technické v Brně. Fakulta architektury, s. 64-73. ISBN 978-80-214-3878-1. [online]. [cit. 14.9.2019]. Dostupné z: $<$ https://dspace.vutbr.cz/bitstream/handle/11012/56729/64-73_kucerova.pdf?sequence $=1$ \&isAllowed $=y>$.

KUČEROVÁ, Z. 2009. Indikátory sociálního pilî̌re udržitelného rozvoje na lokální úrovni In: XIII. Vědecká konference doktorandů. Vysoké učení technické v Brně, Fakulta architektury. s. 6473. ISBN 978-80-214-3878-1. [online]. [cit. 22.9.2019]. Dostupné z: $<$ https://dspace.vutbr.cz/bitstream/handle/11012/56729/64-73_kucerova.pdf?sequence $=1$ \&isAllowed $=y>$.

Leading STAR Community. Indicators. [online]. [cit. 26.9.2019]. Dostupné z https://reporting.starcommunities.org/indicators.

LUPALA, J. M. 2014. The Social Dimension of Sustainable Development: Social inc- lusion in Tanzania's Urban Centres. In: Current Urban Studies. (2) 350-360. [online]. [cit. 17.9.2019]. Dostupné z: <http://file.scirp.org/pdf/CUS_2014122915503807.pdf>.

MEGA, V. - PEDERSEN, J. 1998. Urban Sustainability Indicators. Luxembourg: Office for Official Publications of the European Communities. ISBN 92-828-4669-5. [on-line]. [cit. 25.9.2019]. Dostupné $\quad z$ : <https://www.eurofound.europa.eu/sites/default/files/ef_files/pubdocs/1998/07/en/1/ef9807en.pdf>.

MOLDAN, B. 1996. Indikátory trvale udržitelného rozvoje. Vysoká škola báňská - Technická univerzita Ostrava. Ostrava. ISBN 80-7078-380-X.

MINISTERSTVO ŽIVOTNÍHO PROSTŘEDÍ. 2017. Metodika hodnocení udržitelných měst. [online]. [cit. 9.12.2019]. Dostupné z:https://www.dataplan.info/img_upload/f96fc5d7def29509aeffc6784e61f65b/metodikaur_ko mplet_1.pdf .

Národná sít' Zdravých měst České republiky. Aalborg+10. In: Evropská konference udržitelných měst 2004. [online]. [cit. 15.9.2019]. Dostupné z: https://www.zdravamesta.cz/cb21/archiv/akce/_nszm/nszm07/ls/prez_PetrovaAalborg.pdf. 
Národní sít' Zdravých měst ČR. 2019. Aalborská charta. [online]. [cit. 23.9.2019]. Dostupné z: https://www.zdravamesta.cz/cz/aalborgska-charta-a-aalborske-zavazky.

PETRUCCI, A. - D'ANDREA, S. S. 2002. Quality of Life in Europe: Objective and Subjective Indicators: A Spatial Analysis Using Classification Tech- niques. In: Social Indicators Research. Vol. 60. No. 1/3. [Papers from the Second Annual International Society for Quality of Life Studies Conference]. 55-88. [online]. [cit. 24.9.2019]. Dostupné z: <http://booksc.org/book/26443816/424314>.

POLESE, M. - STREN, R. (eds.). 2000. The Social Sustainability of Cities: Di- versity and the Management of Change. In: Environment \& Urbanization. [online]. [cit. 15.9.2019]. Dostupné z: <https://www.environmentandurbanization.org/social-sustainabi- lity-cities-diversity-andmanagement-change>.

Společné evropské indikátory - ECl. [online]. [cit. 26.9.2019]. Dostupné z: http://ci2.co.cz/cs/spolecne-evropske-indikatory-eci.

Sustainable Cities International. 2012. Indicators for Sustainability: How cities are monito- ring and evaluating their success. [online]. [cit. 26.9.2019]. Dostupné z: <http://sustainablecities.net/wp-content/uploads/2015/10/indicators-for-sustainability-intl-case-studies-final.pdf>.

ŠILHÁNKOVÁ, V. a kol. 2012. Metodika sledování udržitelného rozvoje na místní úrovni. ISBN 978-80-904671-8-7. [online]. [cit. 14.9.2019]. Dostupné z: https://www.researchgate.net/publication/269222017_Metodika_sledovani_udrzitelneho_rozv oje_pro_mesta_a_obce.

TŘEBICKÝ, V. a kol. (eds.). 2009. Indikátory péče: Případové studie z České republiky a Vlámska (Belgie). Praha: Gent [online]. [cit. 17.9.2019]. Dostupné z: <http://www.mmr.cz/getmedia/38949c18-78a6-47bf-b6a1-d87d0fcb73af/Inspirace_01>.

U.S. National Library of Medicine. 2019. Definition for social environment. [online]. [cit. 21.9.2019]. Dostupné z: https://www.definitions.net/definition/social+environment.

UNITED NATIONS. 2016. Nová agenda pro města. Překlad: MMR ČR. [online]. [cit. 23.9.2019]. Dostupné z: <https://www.mmr.cz/getmedia/a29c5c7f-9e94-49a0-a079b763e940546a/NUA- TISK.pdf>.

WESTFALL, M. S. - DE VILLA, V. A. (eds.). 2001. Urban indicators for managing cities. The Asian Development Bank. ISBN 971-561-312-8. [online]. [cit. 26.9.2019]. Dostupné z: $<$ https://www.adb.org/sites/default/files/publication/30020/urban-indi-cators-managingcities.pdf>.

\section{Adresa autorov}

PhDr. Milan Douša

Interný doktorand

Univerzita Pavla Jozefa Šafárika v Košiciach

Fakulta verejnej správy

Popradská 66

04132 Košice 1

E-mail: mil.dousa@gmail.com 
Ing. Lenka Pčolinská, PhD.

Univerzita Pavla Jozefa Šafárika v Košiciach

Fakulta verejnej správy

Popradská 66

04132 Košice 1

E-mail: lenka.pcolinska@upjs.sk 